\title{
DIATOM STRATIGRAPHY OF FA-1 CORE, QARUN LAKE, RECORDS OF HOLOCENE ENVIRONMENTAL AND CLIMATIC CHANGE IN FAIYUM OASIS, EGYPT
}

\author{
Abdelfattah A. Zalat ${ }^{1}$, Leszek Marks², Fabian Welc ${ }^{3}$, Alaa Salem ${ }^{4}$, Jerzy Nitychoruk ${ }^{5}$, \\ Zhongyuan Chen ${ }^{6}$, Aleksandra Majecka ${ }^{2}$, Marcin Szymanek ${ }^{2}$, Marta Chodyka ${ }^{5}$, \\ Anna Tołoczko-Pasek ${ }^{2}$, Qianli Sun ${ }^{6}$, Xiaoshuang Zhao ${ }^{6}$, Jun Jiang ${ }^{6}$ \\ ${ }^{1}$ Tanta University, Faculty of Science, Tanta, Egypt; e-mail: abzalat@science.tanta.edu.eg (corresponding author) \\ ${ }^{2}$ University of Warsaw, Faculty of Geology,Warsaw,Poland; e-mail: leszek.marks@uw.edu.pl, a.majecka@uw.edu.pl, \\ m.szymanek@uw.edu.pl,atoloczko@student.uw.edu.pl \\ ${ }^{3}$ Cardinal Stefan Wyszyński University, Institute of Archaeology, Warsaw,Poland; e-mail: f.welc@uksw.edu.pl \\ ${ }^{4}$ Kafrelsheikh University, Faculty of Science, Kafrelsheikh,Egypt; e-mail: alaa.salem@sci.kfs.edu.eg \\ ${ }^{5}$ John Paul 2nd State Higher School, Faculty of Economic and Technical Sciences, Biała Podlaska, Poland; \\ e-mail:jerzy.nitychoruk@pswbp.pl,wnet.prodziekan@pswbp.pl \\ ${ }^{6}$ East China Normal University, State Key Laboratory of Estuarine and Coastal Research, Shanghai 200062, China; \\ e-mail:z.chen@ecnu.edu.cn,qlsun@sklec.ecnu.edu.cn,xsz_geo@163.com,1012496601@qq.com
}

\begin{abstract}
This study evaluates changes in the environmental and climatic conditions in the Faiyum Oasis during the Holocene based on diatom analyses of the sediment FA-1 core from the southern seashore of the Qarun Lake. The studied FA-1 core was $26 \mathrm{~m}$ long and covered the time span ca. $9.000 \mathrm{cal}$. yrs BP. Diatom taxa were abundant and moderately to well-preserved throughout the core sediments. Planktonic taxa were most abundant than the benthic and epiphytic forms, which were very rare and sparsely distributed. The most dominant planktonic genera were Aulacoseira and Stephanodiscus followed by frequently distribution of Cyclostephanos and Cyclotella species. The stratigraphic distribution patterns of the recorded diatoms through the Holocene sediments explained five ecological diatom groups. These groups represent distinctive environmental conditions, which were mainly related to climatic changes through the early and middle Holocene, in addition to anthropogenic activity during the late Holocene. Comparison of diatom assemblages in the studied sediment core suggests that considerable changes occurred in water level as well as salinity. There were several high stands of the freshwater lake level during humid, warmer-wet climatic phases marked by dominance of planktonic, oligohalobous and alkaliphilous diatoms alternated with lowering of the lake level and slight increases in salinity and alkalinity during warm arid conditions evident by prevalence of brackish water diatoms.
\end{abstract}

Key words: Holocene, environment, climate change, Qarun Lake, diatoms, Faiyum Oasis, Egypt

Manuscript received 25 November 2016, accepted 20 January 2017

\section{INTRODUCTION}

Climate change and human activity are considered the main factors controlled the environmental changes in arid regions like Egypt. The climatic conditions in Egypt have changed many times with successive wet and dry phases during the Holocene time (Hassan, 1996; Zalat, 2015; Welc, 2016). These changes were associated with the climatic change in the North Africa (Said, 1993). The Faiyum Oasis located in northern Egypt is considered as one of the most interesting sites to constructing and understanding the environmental changes during the Holocene in northeastern Africa. It contained a large record of Holocene lacustrine sediments that were deposited in the Faiyum Lake and formed a continuous, natural and unique archive that provided long environmental records with a potentially high time resolution (Zalat, 2015; Marks et al., 2016; Welc, 2016). These sediments contained a wide range of palaeolimnolog- 


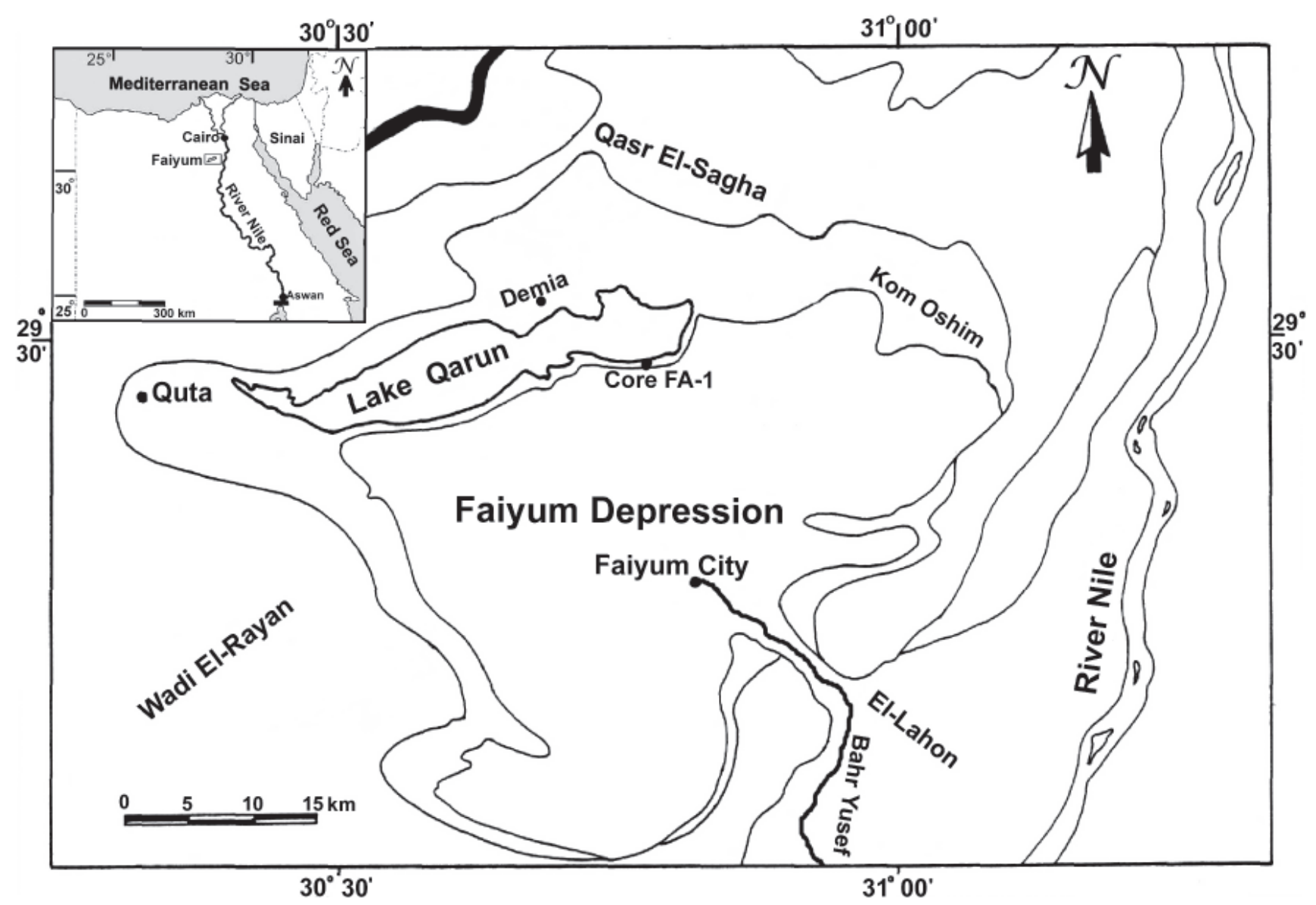

Fig. 1. Location map of Faiyum Oasis showing position of the studied FA-1 core at the southern part of Qarun Lake.

ical indicators such as diatoms, which were very important for environmental monitoring and reconstructing the palaeoenvironmental changes during the prehistoric time (Hall and Smol, 1999; Lotter, 2001; Bigler et al., 2003; Zalat and Servant-Vildary, 2007). In addition, the oasis comprised numerous archaeological sites, mainly of Epipalaeolithic and Neolithic age (Caton-Thompson and Gardner, 1929; Wendorf and Schild, 1976; Hassan, 1986; Schirai, 2010).

Diatom frustules are usually well preserved in many sedimentary environments; thus, many researchers have studied variations in diatom assemblages through sediment cores to describe paleo-lake environments, and how they have changed up to the present time (Fritz et al., 1989). Furthermore, diatoms respond rapidly to environmental changes through time, because they are very sensitive to many ecological factors (Sancetta, 1999; Birks and Koc, 2002). They are unicellular algae, and as biological indicators provide information on habitat types, water depth, alkalinity and salinity levels. Since, water depth and salinity fluctuations have been recognized as indicators of paleoclimatic change, and have provided significant evidences in paleoclimatic reconstruction (e.g. Gasse et al., 1987, 1997; Wilson et al., 1995; Zalat, 2015).

The present research aimed to estimate changes of lake water level and salinity during the Holocene, in order to reconstruct the Holocene climate change in the Faiyum de- pression in Egypt. It was based on fossil diatoms that were preserved in the sediments of the Qarun Lake.

\section{SITE DESCRIPTION}

The Faiyum Oasis is located at the boundary of northern and central Egypt, between latitude $29^{\circ} 00^{\prime}-29^{\circ} 45^{\prime} \mathrm{N}$ and longitude $30^{\circ} 00^{\prime}-31^{\circ} 10^{\prime} \mathrm{E}$, immediately to the west of the Nile Valley and about $90 \mathrm{~km}$ to the south-west of Cairo (Fig. 1). It occupies nearly a triangular depression with an area of about $1700 \mathrm{~km}^{2}$ surrounded by escarpments of the Eocene rock formations. The Oasis is separated from the Nile Valley in the east by a ridge running south from the Giza plateau. Its surface is almost flat and slopes downward in a north-westerly direction from $32 \mathrm{~m}$ a.s.1. to $45 \mathrm{~m}$ b.s.l. at the Qarun Lake, which occupies the lowest part of the depression (Hassan, 1986; Zalat, 2015).

The Faiyum Oasis has a long and rich archaeological history (Caton-Thompson and Gardner, 1934; Ball, 1939; Wendorf and Schild, 1976; Hassan, 1986; Welc, 2016), and there is abundant evidence for human water-based (irrigation) farming activity (Butzer, 1976). It plays an important role in developing the understanding of the Egyptian prehistory, in particular during the Epipalaeolithic-Neolithic time (early to middle Holocene age). 
Today, the Faiyum depression is connected to the Nile Valley by artificial channel, Bahr Yusuf, which enters the depression via the el-Lahun corridor or Hawara Canal. During the Nile floods, the depression received huge amount of freshwater via the canal of Bahr Yusuf and formed during early and middle Holocene a large freshwater lake, named in turn the Paleo-, Pre-, Proto- and Moeris Lake. (Said et al., 1972; Wendorf and Schild, 1976). This ancient lake has left its traces in the desert area surrounding the Oasis in a form of beaches, terraces, or lacustrine diatom deposits located at different altitude. The remnant of this ancient lake survived until the present as the saline and shallow Qarun Lake (Wendorf and Schild, 1976; Hassan, 1986; Zalat, 2015; Marks et al., 2016; Welc, 2016).

The Qarun Lake is located at the northern part of Faiyum depression, (between 29 26'36" - 29॰31'15'N and $30^{\circ} 23^{\prime} 52^{\prime \prime}$ - 30 $\left.49^{\circ} 55^{\prime \prime} \mathrm{E}\right)$ and has an irregular shape of about $40 \mathrm{~km}$ length from east to west and maximum width of $9 \mathrm{~km}$ in the western part, at the El-Karn Island (Fig. 1). Its area of about $234 \mathrm{~km}^{2}$, with depth between 4 to $8.5 \mathrm{~m}$ in the deepest part, and its water level occurs at $45 \mathrm{~m}$ b.s.l. (Baioumy et al., 2010). As it was mentioned, the Lake was fed by a branch of the River Nile - the Bahr Yusuf during the Holocene period (Said et al., 1972; Hassan, 1986; Said, 1990). Today it is an inland closed basin with no natural outlets and its water is trapped inside without any possibility of escaping, except through evaporation (Zalat, 2015).

\section{MATERIAL AND METHODS}

FA-1 core was drilled in the southern part of the Qarun Lake (Fig. 1). A total of 240 representative samples were obtained from the $26 \mathrm{~m}$ long core at $10 \mathrm{~cm}$ intervals for diatom analysis. The diatoms were extracted from the sediment samples according to the procedure proposed by Zalat (2002) and Zalat and Servant-Vildary (2005, 2007). Diatom identification and statistical studies were done in the Geological Department of the Tanta University in Egypt with a use of Carl Zeiss light microscope combined with a digital camera at a normal x100 oil immersion objective. In every rich-diatom slide 1000 diatom valves and in the samples with low-diatom concentrations at least 300 valves were counted. Percentage contents of the species were calculated for estimation of ecological parameters as life-form groups, $\mathrm{pH}$ and salinity. Relative frequencies of every species were calculated as percentage of total diatom valves (\%TDV) in each sample.

Identification and ecological preferences of diatom species were based on previous works (e.g. Hustedt, 1930-1966, 1957; Simonsen, 1962, 1979; Cholnoky, 1968; Ehrlich, 1973, 1975; Stoermer et al., 1974; Foged, 1980, 1993; Kilham et al., 1986; Krammer and Lange-Bertalot, 1986-1991; Gasse, 1986; Zalat, 1991; Denys, 1991-1992; van Dam et al., 1994; Witkowski et al., 2000; Wolfe et al., 2000; Bradbury et al., 2004; Zalat and Servant-Vidary, 2005, 2007). The grouping of diatoms into salinity preference categories has been used for the estimation of the salinity history of the Faiyum Lake.
The ratio of planktonic to benthic and epiphytic forms was calculated for each sample to estimate type of habitats and water level changes. The most dominant species that have relative abundance over $5 \%$ of the total diatom valves in the examined samples were analyzed to determine stratigraphy of the lake sediments (Fig. 2).

\section{LITHOLOGY OF THE FA-1 CORE}

The basal part of the core sequence was composed of massive carbonate clay eluvium (depth 26.00-20.85 m) that was overlain by coarse sand layers at a depth 20.85-19.76 $\mathrm{m}$ (Fig. 2). Above it, there were thin-laminated silts and clays, resembling typical varves, deposition of which was interrupted by a sand at a depth $15.53-15.45 \mathrm{~m}$. A thinly laminated part of the core at a depth of 19.76-13.05 m was composed of white diatomite, carbonate and mostly clayey (terrigenous) laminae.

A considerable lithological change occurred at a depth of $13.05 \mathrm{~m}$ (Fig. 2). Rhythmites common in the lower part of the log were replaced by massive silt and clay with irregular, thick diatomite and ferruginous interbeds. At 12.85-10.04 $\mathrm{m}$, the core was composed mostly of silty clay with whitegrey interbeds, $1-5 \mathrm{~mm}$ thick. Starting from the depth of ca. $8 \mathrm{~m}$ upwards, the core was composed of massive silty clay with sandy interbeds at ca. $7.6 \mathrm{~m}$ and $7.2 \mathrm{~m}$. At 6.9-6.3 m they were replaced by silty clay with dispersed organic matter (plant detritus) and irregular crystals of gypsum.

Lithological characteristics of the sediment at a depth of 6.0-5.6 m indicated stable sedimentary environment, with deposition of steel-gray silty clay, locally interbedded with organic and white-gray lamina. At a depth of 5.5-4.0 m the core was composed of massive gray-brown silty clay. Above, at 4.0-3.4 $\mathrm{m}$ there was loose shell sediment with pieces of malacofauna and mixed with gray sludge silt. The overlying sediment at a depth of 3.4-1.9 m was composed of massive gray-brown silty clay with gravel grains, several $\mathrm{mm}$ in diameter (depth 2.57-2.65 m). Silt at a depth of $2.2 \mathrm{~m}$ was predominated by angular quartz grains (Marks et al., 2016).

\section{RADIOCARBON DATING}

Radiocarbon dating was performed for 32 samples from sediments of the FA-1 core, collected from organic-rich mud layers and mineral deposits with dispersed organic matter (Welc, 2016; Marks et al., in press). AMS dating was done in the Poznan Radiocarbon Laboratory in Poland, where ${ }^{14} \mathrm{C}$ measurements were performed in graphite targets (Goslar et al., 2004). Conventional ${ }^{14} \mathrm{C}$ age was calculated using correction for isotopic fractionation according to Stuiver and Polach (1977). In the calculation procedure, uncertainty of radiocarbon age was determined with a use of counting statistics and standard deviation of partial ${ }^{14} \mathrm{C} /{ }^{12} \mathrm{C}$ results, resulting in the so-called 1-sigma uncertainty of conventional ${ }^{14} \mathrm{C}$ age. Calibration of ${ }^{14} \mathrm{C}$ age was performed using the 


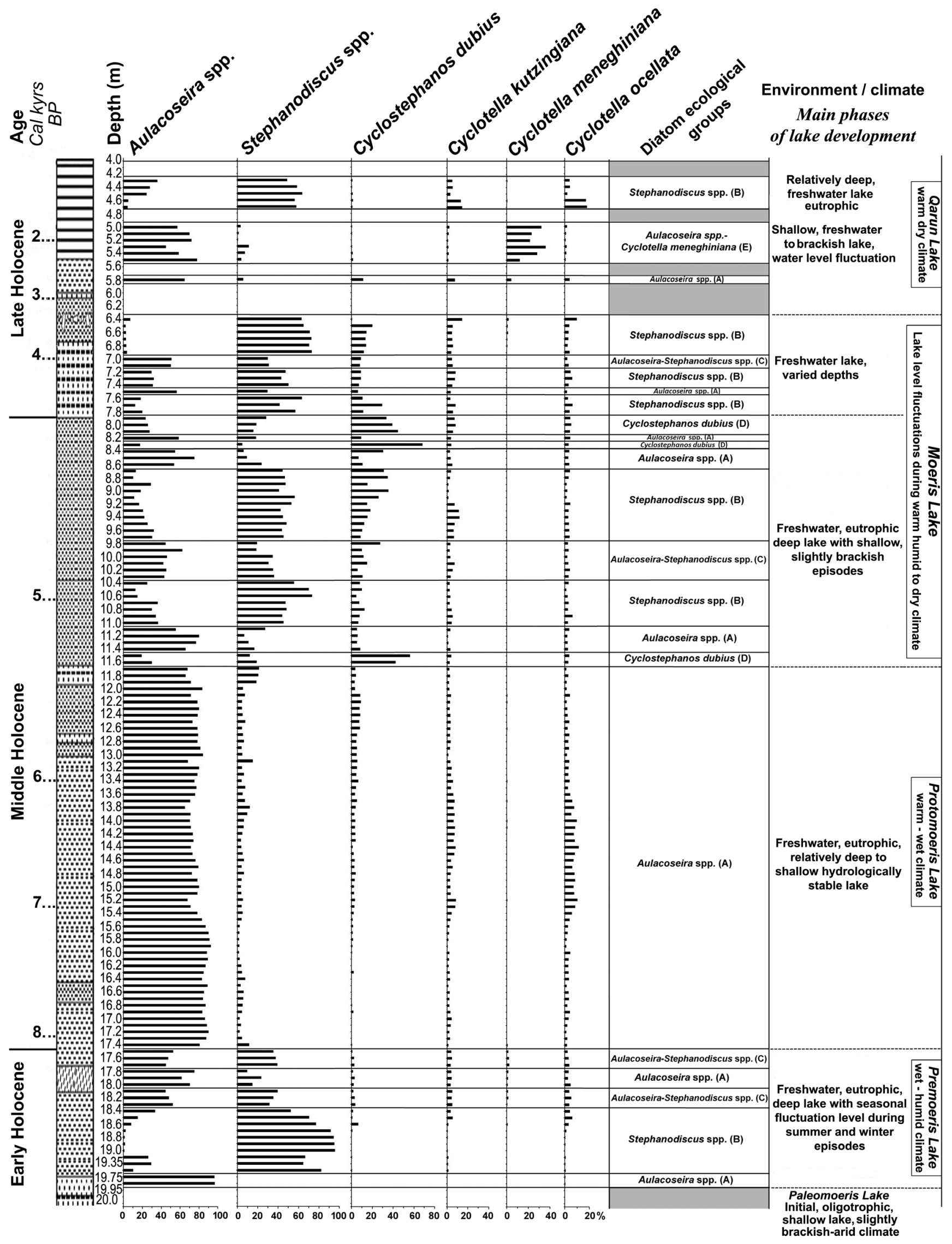

Fig. 2. Diatom stratigraphy of sediments FA-1 core with recognized diatom ecological groups and the main phase of lake developments after Marks et al. (in press), modified. Gray fields at the Diatom ecological groups - Barren of diatoms. 
program OxCal ver. 4.2 (http://c14.arch.ox.ac.uk) designed by the Oxford Accelerator Unit and using the INTCAL13 calibration curve (Reimer et al., 2013).

\section{RESULTS}

Diatom taxa were abundant and moderately to well-preserved throughout the FA-1 core from a depth 19.8 to $6.5 \mathrm{~m}$, and relatively frequent toward the top but with some samples containing poorly preserved sporadic diatoms at depths of 6.3-5.9, 5.7-5.6, 4.9-4.8 and 4.2-4.0 $\mathrm{m}$ (Marks et al., in press). A total of 112 diatom species from 42 genera was recognized. Planktonic taxa were most abundant, reaching to $98 \%$ of the total assemblage, while benthic and epiphytic forms were very rare and sparsely distributed. The most dominant planktonic genus was Aulacoseira with 11 species, followed by the Stephanodiscus with 9 species. Cyclostephanos and Cyclotella species were distributed frequently. Results of diatom analysis and the relative abundance of the dominant taxa have been synthesized in the form of percentage diagrams (Fig. 2). The stratigraphic distribution patterns of the recorded diatoms, variations in content of dominant species and characteristic species in the FA-1 core indicate five diatom ecological groups, which are briefly described.

Aulacoseira granulata ecological group A.- This group is dominated by the planktonic, eutrophication indicator Aulacoseira granulata, accompanied commonly by Aulacoseira granulata var. angustissima, A. ambigua, A. italica and $A$. islandica. The diatom association contains low contents of other planktonic taxa as Stephanodiscus rotula, S. agassizensis, S. alpinus and Cyclostephanos $d u$ bius with sporadic occurrence of Cyclotella ocellata and $C$. meneghiniana. The epiphytic and benthic forms are generally playing a minor role in this group. The assemblage was recorded 8 times throughout the FA-1 core (Fig. 2)

Stephanodiscus spp. ecological group B.-This group is characterized by the highest abundance of planktonic freshwater Stephanodiscus species. Stephanodiscus rotula is the most dominant taxon associated with common occurrence of Stephanodiscus neoastraea, S. agassizensis, S. alpinus, S. aegyptiacus, S. hantzschii, and S. niagarae. The diatom association is represented by frequently distribution of other planktonic freshwater taxa Aulacoseira granulata, $A$. italica and A. islandica, associated with sporadic occurrence of Cyclotella kützingiana, C. ocellata and C. meneghiniana. The epiphytic taxa including Epithemia spp., Cocconeis placentula and Staurosira-Staurosirella spp are sparsely distributed with limited numbers of benthic forms. This group was observed seven times at different stratigraphic levels in the FA-1 core.

Aulacoseira-Stephanodiscus spp. ecological group C.This group was represented by mixed assemblage of common occurrence Aulacoseira spp. and Stephanodiscus spp.
(80-90\%). Other planktonic taxa as Cyclotella kützingiana, C. ocellata and Cyclostephanos dubius were distributed sporadically. The assemblage was recorded three times in the FA-1 core. The diatom group of Aulacoseira and Stephanodiscus spp. was indicative of high stand lake level with developed nutrient availability.

Cyclostephanos dubius ecological group D.-This group was distinguished by high abundance of Cyclostephanos dubius (40-55\%), accompanied by Aulacoseira spp., which was more abundant than Stephanodiscus taxa. Other planktonic taxa as Cyclotella kützingiana and C. ocellata were distributed frequently. This group was observed 3 times in the studied core. The epiphytic and benthic forms are recorded sporadically in limited numbers.

Aulacoseira granulate-Cyclotella meneghiniana ecological group E.- The group was dominated by planktonic taxa Aulacoseira spp. with relative abundance ranges between 50 to $75 \%$, associated with significant common occurrence of Cyclotella meneghiniana (25-40\%). Aulacoseira taxa included A. granulata, A. granulata var. angustissima, A. italica, and $A$. islandica. The others Stephanodiscus spp. and Cyclotella spp. are distributed sporadically. The benthic and epiphytic groups are represented by few taxa dispersed sparsely. This ecological group was observed at the top part of FA-1 core, with thickness $.05 \mathrm{~m}$ at depth 5.0-5.5 m.

\section{DISCUSSION}

Analysis of sedimentary diatoms in the FA-1 core reveal limnological changes during the Holocene that are related mainly to climate change, anthropogenic activities and natural disturbance. The stratigraphic distribution pattern of the recorded diatom taxa (Fig. 2) indicated seasonal and annual changes in the diatom assemblage, which divided the FA-1 core sequence into 28 units of these 5 units with sporadic occurrence of poorly preserved diatoms and 23 units represented by well preserved, high abundance of diatoms included in five ecological groups.

Aulacoseira granulata ecological group A is characterized by maximum abundance of Aulacoseira granulata associated with commonly appearance of Aulacoseira granulata var. angustissima, A. ambigua, A. italic, A. agassizii and $A$. islandica.. Aulacoseira granulata was recognized as a freshwater planktonic and alkaliphilous species, common in eutrophic water of higher silica and temperature (Hustedt, 1957; Ehrlich, 1973; Stoermer et al., 1974; Kilham et al., 1986). On the other hand, most of the Aulacoseira species indicated high growth requirements for silicon and demanded high silica content in water (Kilham and Kilham, 1971), presumably in different combinations of phosphorus and light (Kilham et al., 1986). Aulacoseira species were non-competitive, so their wide distribution normally coincided with low concentration of other diatoms (Wolfe et al., 2000). These taxa are also indicators of warmer climate, which may have led to wind-induced 
mixing in the lake, higher input of humic substances and increased precipitation (Laing and Smol, 2003). Moreover, Aulacoseira ambigua required increased turbulence to remain in a photic zone and reported high concentration of total phosphorus (TP) (Kilham et al., 1986; Fritz et al., 1993). Aulacoseira granulata and A. ambigua had summer blooms, which documented increasing moisture, greater flow through and higher lake level (Bradbury et al., 2004).

Predominance of Aulacoseira species of ecological group A through several units in the studied FA-1 core denoted summer with high silica concentration. This ecological group was recorded in the early Holocene (19.6-19.8 $\mathrm{m}, 17.8-18.0 \mathrm{~m})$, the middle Holocene interval (11.7-17.4 m, 11.1-11.4 m, 8.4-8.6 m, 8.15-8.20 m, 7.45-7.50 m); and the late Holocene at depth 5.75-5.80 m. Maximum abundances of Aulacoseira granulata associated with other Aulacoseira species and decreased abundance of Stephanodiscus and Cyclotella species could reflect a freshwater lake with relatively high level due to nutrient-rich influx from the Nile during a wet warm period. Moreover, maxima abundance of Aulacoseira species suggest stabilized conditions; remaining wet and windy with increased turbulence and upwelling in the lake, typical of a late phase of the Nile flood cycle (cf. Zalat, 1995). However, frequent occurrence of Aulacoseira distans in some intervals of the core pointed out probably to a slight tendency towards acidification of the lake with moderate decrease in $\mathrm{pH}$ of lake water, because $A$. distans was an acidophilous diatom, indicating $\mathrm{pH}<7$ (van Dam et al., 1994). This might confirm a higher terrestrial nutrient supply with freshwater from the Nile during wet rainy periods.

Stephanodiscus spp. ecological group B is distinguished by highest abundance of planktonic freshwater Stephanodiscus species with relative frequency of $60-83 \%$ of the total assemblage. This group includes Stephanodiscus rotula, S. agassizensis, S. minutulus, S. aegyptiacus, S.neoastraea, S. alpinus, S. hantzschii and S. niagarae. These taxa were known to occupy slightly alkaline and eutrophic freshwater with low silica content (Gasse, 1986; Kilham et al., 1986; Zalat and Servant-Vildary, 2007). Stephanodiscus minutulus competed well for silicon but needed a plentiful supply of $\mathrm{P}$ and hence, it was more common in waters with relatively low silicon/phosphorus ratios (Kilham and Kilham, 1978). This species became frequently abundant in a spring diatom bloom of lakes enriched in P (Bradbury, 1975, 1988). Stephanodiscus taxa were dominant in winter and spring when increased turbulence could suspend these relatively heavy diatoms, therefore they could denote moist winters and springs with active circulation (cf. Bradbury, 1992; Bradbury et al., 2004). Dominance of small and intermediate-sized Stephanodiscus species $(S$. minutulus, $S$. hantzschii, and $S$. agassizensis) characterized spring bloom when nutrient loading was related to spring runoff, along with Aulacoseira granulata. The increased abundance of planktonic Stephanodiscus species reflected a high lake level, because of freshwater influx by the Nile and increased nutrient loading to the lake with low $\mathrm{Si}$ and high $\mathrm{P}$ supply rates prevailing at time of deposition (Zalat,
2015). These ecological conditions were repeated several times through the early Holocene (18.40-19.55 m), middle Holocene (10.40-11.05 m, 8.7-9.7 m, 7.6-7.8 m, 7.2-7.4 m) and late Holocene $(6.4-6.9 \mathrm{~m}, 4.3-4.7 \mathrm{~m})$. This reflects seasonal lake level fluctuations with rising slightly alkaline freshwater level several times during wet or humid climate in the Holocene (winter-spring season?).

Aulacoseira-Stephanodiscus spp. ecological group C was represented by mixed assemblage of common occurrence Aulacoseira spp. and Stephanodiscus spp. with relative frequency of $80-90 \%$ of the total assemblage. The group was recorded four times with different thickness in the FA-1 core at depths $18.1-18.3 \mathrm{~m}, 17.5-17.7 \mathrm{~m}$. The appearance of Aulacoseira-Stephanodiscus spp. ecological group was indicative of deep lake with enhanced nutrient availability by repeated Nile water inflows to the lake at the transition of spring and summer.

Cyclostephanos dubius ecological group D was signified by high abundance of Cyclostephanos dubius (40$55 \%$ ), associated with frequently occurrence of Aulacoseira spp., and Stephanodiscus taxa. This group was detected 3 times and had small thickness in the studied core. Cyclostephanos dubius was considered as a pelagic taxon, common in flowing and stagnant water in coastal area, oligosaprobic, alkalibiontic, halophilous " $0.0-5 \mathrm{~g} / \mathrm{l}$ ” (Hustedt, 1930, 1957); eutrophic, in fresh and brackish water, $\mathrm{pH}$ value 6.99.0 (van Der Werff and Huls, 1957, 1974); planktonic, brackish water form (Cholnoky, 1968); halophilous, alkalibiontic, with pH value above 7.0 (Foged, 1973). The diatom assemblage of this ecological group is indicating a relatively high stand lake level with clear dominance of eutrophic freshwater conditions and slightly higher salinity and alkalinity through short time of warm-dry interval.

Aulacoseira spp.-Cyclotella meneghiniana ecological group E was characterized by high abundance of Aulacoseira spp. associated with commonly occurrence of Cyclotella meneghiniana. Other planktonic taxa including Stephanodiscus spp. and Cyclotella spp. were rare. This ecological group was recorded only once, with thickness of about $0.5 \mathrm{~m}$. Cyclotella meneghiniana was recorded ecologically as a facultative planktonic taxon favored by moderately alkaline conditions (Hecky and Kilham, 1973; Richardson et al., 1978), in coastal and estuarine locations with water of varied chemistry (cf. Trigueros and Orive, 2000; Tibby and Reid, 2004). Its optimal development occurred at $20.1-20.6^{\circ} \mathrm{C}$ (Stoermer and Ladewski, 1976) but it was eurythermal (Gasse, 1986). It was reported from brackish water of the coastal Egyptian lakes, being dominant in spring and at the beginning of summer at water temperature $29-31^{\circ} \mathrm{C}$ (Zalat and ServantVildary, 2005, 2007). Common occurrence of Cyclotella meneghiniana with high abundance of Aulacoseira species and frequently to low amounts of Stephanodiscus taxa reflected warm eutrophic freshwater conditions with slight increased salinity and alkalinity during the time of deposition in the late Holocene.

In general, diatom analysis of lake sediments enabled to distinguish several freshwater and brackish conditions in the lake development during the Holocene (Marks et 
al., in press). At the beginning of early Holocene through the depth 19.95-26.0 m (ca. 9.5-8.7 cal kyrs BP), this unit is characterized by sandy muddy facies intercalated with bedded sand and completely barren to scarcely poorly preserved some heavily silicified diatom taxa. However, Zalat (1996) was recorded commonly abundance of Nitellopsis obtusa associated with sporadic occurrence of some chara taxa in the early Holocene unit that correspond to the basal unit of FA-1 core and suggested oligotrophic freshwater environment of a relatively deep lake with depth of about 4-12 m. This lake was coinciding with the Paleomoeris Lake, which had a low water level due to reduced annual influx from the Nile River (e.g. Hassan, 1986, 1988; Wenke et al., 1988; Kozłowski and Ginter, 1993). The absence of diatoms or rarely occurrence of poorly preserved forms could result from lowering levels of primary productivity, where the lake had poor nutrients in the early phase of the unstable connection between the Nile and the Faiyum depression.

Abrupt change in the environmental conditions occurred with deposition of diatom unit that completely dominant by Aulacoseira species. This phase was a result of distinct connection with the Nile and influx of freshwater into the Faiyum depression to the Premoeris Lake 8.8-8.2 cal kyrs BP (according to Wendorf and Schild, 1976). This interval was dominated by eutrophic freshwater planktic taxa, with peak abundance of Aulacoseira spp. (98\%) of ecological group (A) (19.6-19.8 m), which suggests high trophic status of slightly alkaline freshwater environment. The rising lake level was continued to become deeper and the followed Stephanodiscus spp. ecological group (B) was flourished at depth 18.40-19.55 m. The early Holocene terminated with mixed assemblage of Aulacoseira spp.-Stephanodiscus spp. ecological group (C) at depth 17.45-17.70 m (ca. 8.2 cal kyrs BP). The predominance of these planktonic ecological groups A, B and C during the early Holocene suggests that the early Premoeris lake basin was already quite deep, freshwater, eutrophic and slightly alkaline environment during the wet climate. The prevalence of riverine taxa indicates increased discharge of the Nile water into the lake.

The middle Holocene started with lowering of the lake level to form slightly deep to relatively shallow hydrologically stable (late Premoeris and Protomoeris Lake) in the Faiyum depression in a long interval (8.2-5.4 cal kyrs $\mathrm{BP})$, which was characterized by eutrophic, slightly alkaline freshwater environment with high silica concentration during warm-wet climate. This was followed by seasonal and annual changes in the diatom assemblages, which reflect seasonal fluctuations in lake level, between high stand freshwater and low stand slightly brackish water during warm and dry conditions through the period ca. 5.4-4.0 cal kyrs BP (Moeris Lake) due to the gradual disappearance of the hydrological connection between Faiyum Oasis and the Nile. In the late Holocene, the lake has been continuously diminished and shallower, presumably due to occasional disconnection to the Nile. But through some intervals, 3.9-3.4 cal kyrs BP, the lake water level returned to become relatively high with great abundance of Stephanodiscus spp. ecological group B, which point to deep, eutrophic and slightly alkaline freshwater environment most probably due to increased local rainfall episodes in the Faiyum area and occasional high stand of the Nile. The lower concentration of diatom valves at some depths $(6.3-5.6,4.95-4.8,4.9,42-4.0 \mathrm{~m})$, particularly in the sandy units, may be due to lower diatom productivity. The upper part of the core (3.9-2.0 m) was completely barren of diatom frustules, reflecting marked environmental changes in the lake, connected with transition from freshwater through brackish to saline conditions.

\section{CONCLUSIONS}

Summarized in terms of diatom results, the environmental conditions and climatic changes in the Faiyum depression during the Holocene are interpreted as follows:

1) Freshwater, eutrophic, slightly alkaline episodes with relatively high stand lake level characterized by high silica during warm-humid climate (summer phase) coincide with maximum abundance of planktonic Aulacoseira spp. ecological group (A).

2) Deep open freshwater, eutrophic, slightly alkaline episodes with high stand lake level characterized by low silica and high phosphorus during cold to temperate -wet climate (winter-spring phase) coincide with maximum abundance of planktonic Stephanodiscus spp. ecological group (B).

3) Deep freshwater, eutrophic, slightly alkaline with enhanced nutrient availability by repeated Nile water inflows to the lake at the transition of spring and summer climate represented by mixed assemblage of Aulacoseira and Stephanodiscus spp. ecological group (C).

4) Slightly brackish, eutrophic shallow water environment with increased alkalinity and salinity during warmdry conditions and represented by high abundance of Cyclostephanos dubius ecological group (D).

5) Slightly brackish, eutrophic, alkaline shallow water and relatively lowering lake-level during summer warm and dry conditions represented by great abundance of planktonic diatoms of Aulacoseira-Cyclotella meneghiniana ecological group (E).

\section{Acknowledgements}

The project was funded by the National Science Centre in Poland (decision no. DEC 2012/05/B/ST10/00558). The authors are grateful to the Centre of Mediterranean Archaeology of the University in Warsaw and particularly to Dr. Zbigniew Szafrański for a logistic support during fieldworks in Egypt.

\section{REFERENCES}

Baioumy, H.M., Kayanne, H., Tada, R., 2010. Reconstruction of lakelevel and climate changes in Lake Qarun, Egypt, during the last 7000 years. Journal of Great Lakes Research 36, 318-327.

Ball, J., 1939. A contribution to the Geography of Egypt. Survey and Mines Department, Cairo.

Bigler, C., Grahn, E., Larocque, I., Jeziorski, A., Hall, R., 2003. Holo- 
cene environmental change at Lake Njulla (999 m a.s.1.), northern Sweden: a comparison with four small nearby lakes along an altitudinal gradient. Journal of Paleolimnology 29, 13-29.

Birks, C.J.A., Koc., N., 2002. A high-resolution diatom record of lateQuaternary sea-surface temperatures and oceanographic conditions from the eastern Norwegian Sea. Boreas 31, 323-344.

Bradbury, J.P., 1975. Diatom stratigraphy and human settlement in Minnesota. Geological Society of America, Special Paper 171, 1-74.

Bradbury, J.P., 1988. A climate-limnological model of diatom succession for palaeolimnological interpretation of varved sediments in Elk Lake. Journal of Palaeolimnology 1, 115-131.

Bradbury, J.P., 1992. Late Cenozoic lacustrine and climatic environments at Tule Lake, northern Great Basin, USA. Climate Dynamics 6, 275-284.

Bradbury, J.P., Colman, S.M., Dean, W.E., 2004. Limnological and climatic environments at Upper Klamath Lake, Oregon during the past 45,000 years. Journal of Palaeolimnology 31, 167-188.

Butzer, K.W., 1976. Early Hydraulic Civilisation in Egypt, a Study in Cultural Ecology. The University of Chicago Press, Chicago.

Caton-Thompson, G., Gardner, E.W., 1929. Recent work on the problem of Lake Moeris. Geographical Journal 73, 20-60.

Caton-Thompson, G., Gardner, E.W., 1934. The Desert Faiyum. Royal Anthropological Institute, London.

Cholnoky, B.J., 1968. Die Ökologie der Diatomeen in Binnengewassern. Cramer Verlag, Berlin, 699 pp.

Denys, L., 1991-1992. A check-list of the diatoms in the Holocene deposits of the western Belgian coastal plain with a survey of their apparent ecological requirements. I. Introduction, ecological code and complete list. Professor Paper Belgium Geological Survey 246, $1-41$.

Ehrlich, A., 1973. Quaternary diatoms of the Hula Basin (northern Israel). Bulletin Geological Survey Israel 58, 1-39.

Ehrlich, A., 1975. The Diatoms from the surface sediments of the Bardawil Lagoon (Northern Sinai) - Paleoecological significance. Nova Hedwigia 53, 253-277.

Foged, N., 1973. Diatoms from southwest Greenland. Medd. Om Grønland 194, 1-84.

Foged, N., 1980. Diatoms in Egypt. Nova Hedwigia 33, 629-707.

Foged, N., 1993. Some diatoms from Siberia, especially from Lake Baikal. Diatom Research 8, 231-279.

Fritz, S.C., Stevenson, A.C., Patrick, S.T., Appleby, P.G., Oldfield, F., Rippey, B., Natkanski, J., Battarbee, R.W., 1989. Paleolimnological evidence for the recent acidification of Llyn, Hir, Dyfed, Wales. Journal of Paleolimnology 2, 245-262.

Fritz, S.C., Juggins, S.R., Battarbee, W., 1993. Diatom assemblages and ionic characterization of lakes of the Northern Great Plains, North America: A tool for reconstructing past salinity and climate fluctuations. Canadian Journal of Fisheries and Aquatic Sciences 50, 1844-1856.

Gasse, F., 1986. East African diatoms, taxonomy, ecological distribution. Bibliotheca Diatomologica 2, 1-201.

Gasse, F., Fontes, J.C., Plaziat, J.C., Carbonel, P., Kaczmarska, I., De Deckker, P., Soulie-Marsche, I., Callot, Y., Dupeuble, P.A., 1987. Biological remains, geochemistry and stable isotopes for the reconstruction of environmental and hydrological changes in the Holocene lakes from north Sahara. Palaeogeography, Palaeoclimatology, Palaeoecology 60, 1-46.

Gasse, F., Barker, P., Gell, P.A., Fritz, S.C., Chalie, F., 1997. Diatominferred salinity in palaeolakes: An indirect tracer of climate change. Quaternary Science Reviews 16, 547-563.

Goslar, T., Czernik, J., Goslar, E., 2004. Low-energy ${ }^{14}$ C AMS in Poznań Radiocarbon Laboratory, Poland. Nuclear instruments and methods in physics research section B: Beam Interactions with Materials and Atoms 223-224, 5-11.

Hall, R.I., Smol, J.P., 1999. Diatoms as indicators of lake eutrophication. In: Stoermer, E.F., Smol, J.P. (Eds), The Diatoms: Applica- tions for the Environmental and Earth Sciences,128-168, Cambridge University Press.

Hassan, F.A., 1986. Holocene lakes and prehistoric settlements of the Western Faiyum. Journal of Archaeological Science 13, 483-501.

Hassan, F.A., 1988. The Predynastic of Egypt. Journal of World Prehistory 2, 135-185.

Hassan, F.A., 1996. Abrupt Holocene climatic events in Africa. In: Pwiti, G., Soper, R. (Eds), Aspects of African Archaeology. Papers from the 10th Congress Pan-African Association for Prehistory and Related Studies, 83-89, Harare.

Hecky, R.E., Kilham, P., 1973. Diatoms in alkaline, saline lakes: ecology and geochemical significance. Limnology and Oceanography $18,53-71$

Hustedt, F., 1930. Bacillariophyta (Diatomae). In: Pascher, A. (Ed.), Die Süsswasser-Flora Mitteleuropas 10, 466 pp., Koelts, Koenigstein, Germany.

Hustedt, F., 1930-1966. Die Kieselalgen. In: L. Rabenhorst (Ed.), Kryptogamenflora von Deutschland, Oesterreich und der Schweiz, Akademische Verlagsgesellschaft, Leipzig, 1, 1-920, 2, 1-845, 3, 1-816.

Hustedt, F., 1957. Die Diatomeenflora des Fluss-systems der Weser im Gebiet der Hansestadt Bremen. Abhandlungen der NaturwissenschaftlichenVerein zu Bremen 34, 181-440.

Kilham, P., Kilham, S.S., 1971. Melosira granulata (Ehr.) Ralfs: morphology and ecology of a cosmopolitan freshwater diatom. Verhandlungen der Internationalen Vereinigung Limnologie 19, 2716-2721.

Kilham, P., Kilham, S.S., Hecky, R.E., 1986. Hypothesized resource relationships among African planktonic diatoms. Limnology and Oceanography 31, 1169-1181.

Kilham, S.S., Kilham, P., 1978. Natural community bioassays: predictions of results based on nutrient physiology and competition. Verhandlungen Internationale Vereinigung für Theoretische und Angewandte Limnologie 20, 68-74.

Kozłowski, J.K., Ginter, B., 1993. Holocene change in the Faiyum; Lake Morris and the evolution of the Climate in Northeastern Africa. In: Krzyżaniak, L., Kobusiewicz, M. (Eds), Environmental change and human culture in the Nile Basin and northern Africa until the Second Millenium BC, 327-336, Poznań.

Krammer, K., Lange-Bertalot, H., 1986-1991. Bacillariophyceae. In: Ettl, H., Gerloff, J., Heynig, H., Mollenhauer, D. (Eds), Süsswasserflora von Mitteleuropa 2 (1-4). Gustav Fischer Verlag, Stuttgart/ Jena.

Laing, T.E., Smol, J.P., 2003. Late Holocene environmental changes inferred from diatoms in a lake on the western Taimyr Peninsula, northern Russia. Journal of Paleolimnology 30, 231-247.

Lotter, A. F., 2001. The effect of eutrophication on diatom diversity: examples from six Swiss lakes. In: Jahn, R., Kocioleck, J.P., Witkowski, A., Compère, P. (Eds), Lange-Bertalot-Festschrift, 417432, Ruggel, Gantner.

Marks, L., Salem, A., Welc, F., Nitychoruk, J., Chen, Z., Zalat, A., Majecka, A., Chodyka, M., Szymanek, M., Tołoczko-Pasek, A. 2016. Preliminary report on unique laminated Holocene sediments from the Qarun Lake in Egypt. Studia Quaternaria 33 (1), 35-46.

Marks, L., Salem, A., Welc, F., Nitychoruk, J., Chen, Z., Blaauw, M., Zalat, A., Majecka, A., Szymanek, M., Chodyka, M., TołoczkoPasek, A., Sun, Q., Zhao, X., Jiang, J., in press. Holocene lake sediments from the Faiyum Oasis in Egypt: a record of environmental and climate change.

Reimer, P.J., Bard, E., Bayliss, A., Beck, J.W., Blackwell, P.G., Bronk Ramsey, C., Buck, C.E., Cheng, H., Edwards, R.L., Friedrich, M., Grootes, P.M., Guilderson, T.P., Haflidason, H., Hajdas, I., Hatté, C., Heaton, T.J., Hoffmann, D.L., Hogg, A.G., Hughen, K.A., Kaiser, K.F., Kromer, B., Manning, S.W., Niu, M., Reimer, R.W., Richards, D.A., Scott, E.M., Southon, J.R., Staff, R.A., Turney, C.S.M., van der Plicht, J., 2013. IntCal13 and Marine13 radiocarbon age calibration curves 0-50,000 years cal BP. Radiocarbon 55 (4), 1869-1887. 
Richardson, J.L., Harvey, T.J., Holdship, S.A., 1978. Diatoms in the history of shallow East African lakes. Polskie Archiwum Hydrobiologii 25, 341-343.

Sancetta, C., 1999. Diatoms and paleoceanography. In: Stoermer, E.F., Smol, J.P. (Eds), The diatoms: Applications for the environmental and earth sciences, 374-386, New York, Cambridge University Press.

Said, R., 1990. Cenozoic. In: Said, R. (Ed.), The Geology of Egypt, 451-486, Rotterdam, Netherlands, A. A. Balkema Publishers.

Said, R., Wendorf, F., Albritton, G., Schild, R., Kobusiewicz, M., 1972. Remarks on the Holocene geology and archaeology of Northern Faiyum Desert. Archaeologica Polona 13, 7-22.

Shirai, N., 2010. The Archaeology of the First Farmer-Herders in Egypt. New Insights into the Fayum Epipalaeolithic and Neolithic. 389 pp., Leiden University Press.

Simonsen, R., 1962. Untersuchungen zur Systematik und Ökologie der Bodendiatomeen der westlichen Ostsee. Internationale Revue der Gesamten Hydrobiologie. Systematische Beihefte 1, 1-144.

Simonsen, R., 1979. The diatom system: Ideas on phylogeny. Bacillaria $2,9-72$.

Stoermer, E.F., Ladewski, T.B., 1976. Apparent optimal temperatures for the occurrence of some common phytoplankton species in southern Lake Michigan. Great Lakes Research Division, Institute of Science and Technology, University of Michigan, Ann. Arbor, MI, GLRD Special Report 18, 1-49.

Stoermer, E.F., Bowman, M., Kingston, J.C.V., Schaedel, A.L., 1974. Phytoplankton composition and abundance in Lake Ontario during IFYGL. Special Report 53. Great Lakes Research Division, Ann. Arbor.

Stuiver, M., Polach, H.A., 1977. Discussion reporting of $\mathrm{C}^{14}$ data. Radiocarbon 19, 355-363.

Tibby, J., Reid, M., 2004. A model for inferring past conductivity in low salinity waters derived from Murray River diatom plankton. Marine and Freshwater Research 55, 587-607.

Trigueros, M., Orive, E., 2000. Tidally driven distribution of phytoplankton blooms in a shallow, macrotidal estuary. Journal of Plankton Research 22, 969-986.

van Dam, H., Mertens, A., Sinkeldam, J., 1994. A coded checklist and ecological indicator values of freshwater diatoms from the Netherlands. Netherlands Journal of Aquatic Ecology 28, 117-133.

van der Werff, A., Huls, H., 1957. Diatomeënflora van Nederland. Drukkerij Sprey Abcoude 1, 1-8. van der Werff, A., Huls, H., 1974. Diatomeenflora van Nederland 10. De Hoe.

Welc, F., 2016. Holocene climate change in the Lower Nile Basin based on geoarchaeological data froam the Faiyum Oasis (Egypt), 267-281, Warsaw.

Wendorf, F., Schild, R., 1976. Prehistory of the Nile Valley, 222-226, Academic Press, New York.

Wenke, R.J., Long, J.E., Buck, P.E., 1988. Epipalaeolithic and Neolithic subsistence and settlement in the Faiyum Oasis in Egypt. Journal of Field Archaeology 15 (1), 29-51.

Wilson, S.E., Cumming, B.F., Smol, J.P., 1995. Assessing the reliability of salinity inference models from diatom assemblages: an examination of a 219-lake data set from western North America. Canadian Journal of Fisheries and Aquatic Science 53, 1580-1594.

Witkowski, A., Lange-Bertalot, H., Metzeltin, D., 2000. Diatom flora of marine coasts I, Iconographia Diatomologica 7, 1-925.

Wolfe, A.P., Fréchette, B., Richard, P.J.H., Miller, G.H., Forman, S.L., 2000. Palaeoecological assessment of a 90,000-year lacustrine sequence from Fog Lake, Baffin Island, Arctic Canada. Quaternary Science Reviews 19, 1677-1699.

Zalat, A.A., 1991. Paleontological studies on the Quaternary Diatomite of the Fayoum Depression, Western Desert, Egypt. Ph.D. dissertation, 329 pp., Tanta University, Egypt.

Zalat, A.A., 1995. Calcareous nannoplankton and diatoms from the Eocene/Pliocene sediments, Fayoum depression, Egypt. Journal of African Earth Sciences 20, 227-244.

Zalat, A.A., 1996. Charophyte gyrogonites from Holocene Lacustrine Sediments of the Fayoum Depression, Egypt. Neues Jahrbuch für Geologie und Paläontologie Beiheft 8, 502-516.

Zalat, A.A., 2002. Distribution and origin of diatoms in the bottom sediments of the Suez canal lakes and adjacent areas, Egypt. Diatom Research 17 (1), 243-266.

Zalat, A.A., 2015. Holocene diatom assemblages and their palaeoenvironmental interpretations in Fayoum Depression, Western Desert, Egypt. Quaternary International 369, 86-98.

Zalat, A.A., Servant-Vildary, S., 2005. Distribution of diatom assemblages and their relationship to environmental variables in the surface sediments of three northern Egyptian lakes. Journal of Palaeolimnology 34, 159-174.

Zalat, A.A., Servant-Vildary, S., 2007. Environmental change in northern Egyptian Delta lakes during the late Holocene, based on diatom analysis. Journal of Palaeolimnology 37, 273-299. 